\title{
POLITIVOLDENS GRENSER
}

\section{Av Anders Bratholm}

Redaktøren av tidsskriftet har gitt meg anledning til å komme med noen bemerkninger til Kochs artikkel.

Jeg har inntatt det standpunkt under den diskusjon som har fulgt avgivelsen av Politivoldrapporten på oppdrag av det norske justisdepartement, at jeg ikke har villet delta i noen polemikk om rapporten.

Jeg skal her nøye meg med å påpeke et par forhold:

I Kriminalistisk Instituts stencilserie nr. 17 kommer Koch mer grundig inn på Politivoldrapporten, og det er rimelig at han ikke finner grunn til å gjenta dette i tidsskriftet. Det kan likevel være av interesse for de lesere som ikke har adgang til å lese nr. $17 \mathrm{i}$ stencilserien å vite at helt sentrale vitner for det norske politivoldutvalg var nåværende og tidligere polititjenstemenn, i tillegg til de mange andre vitner. I alt avhørte utvalget 101 personer. Utvalget la også stor vekt på hva tre norske leger kunne fortelle om omfanget og arten av politivold ved Bergen politikammer i forbindelse med at de som medisinske studenter i lang tid tok blodprøve av innbrakte mistenkte. Et par av legene ga som forklaring på at de kunne observere så meget av interesse at de etter en tid ble betraktet av politiet "som en av dem «.

Jeg har mine tvil om forskere som følger politiet $\mathrm{i}$ dets arbeid vil bli betraktet "som en av dem", selv om nok en del interessante observasjoner kan gjøres.

Til slutt: Jeg tror det er viktig i debatten om politivold å skille mellom de tilfelle hvor politiet på grunn av en provokasjon kan bli fristet til å gå noe over streken og de mer grove overgrep. Selv om det ikke er noen klar grense mellom de to grupper tilfelle, tror jeg likevel at det er mulig ved en nærmere undersøkelse å plassere de fleste av de forekommende tilfelle innenfor en av gruppene.

Adresse: Professor, dr. jur. Anders Bratholm

Institutt for kriminologi og strafferett

Universitetet i Oslo

Karl Johans gt. 47, Oslo 1, Norge 